\title{
Characterization of cultivars and low-temperature pollen grain storage in amaryllis (Hippeastrum sp.)
}

\author{
Naiara Vallado de Almeida ${ }^{1}$, Camila Y. Nishimura Saziki², Jean Carlos Cardoso ${ }^{1,3^{*}}$ (D)
}

10.1590/0034-737X201966060006

\begin{abstract}
The determination of viability and the preservation of pollen grains are useful tools for breeding of ornamentals, especially when the synchronization of flowering between species or cultivars does not occur naturally. Thus, the objective of this study was to characterize the flowering and to evaluate the preservation and maintenance of the viability of pollen grains in cultivars of amaryllis (Hippeastrum sp.) subjected to three storage temperatures. Anthers of five cultivars of amaryllis were collected from 12 to 24 hours after anthesis. One part of the anthers was immediately used for germination tests using in vitro germination in culture medium and the other part was stored at temperatures of 25 , 8 and $-20^{\circ} \mathrm{C}$. Pollen grains were germinated in culture medium at $0,20,75,125,165,205$ and 245 days after storage. All cultivars of amaryllis showed an accelerated loss of viability at $25^{\circ} \mathrm{C}$ storage temperature. The 'Bull' cultivar showed higher recalcitrance to cold-storage, while 'Intokazie' and 'Pink Panther' cultivars showed higher longevity and higher percentage of germination along storage. The temperature of $-20^{\circ} \mathrm{C}$ resulted in the best responses for the maintenance of the integrity and preservation of the viability of pollen grains of different cultivars of amaryllis.
\end{abstract}

Key-words: reproductive development; ornamental; breeding; pollen preservation; hybridization.

\section{INTRODUCTION}

The preservation of a pollen grain can be understood as the maintenance of its viability after long periods of storage (Vaknin \& Ieisikowitch, 2000) and this is a very important procedure for plant breeding programs because it facilitates the exchange of germplasm and conservation of genetic resources, besides allowing the crossing between species or cultivars with different flowering synchronyzation, allowing the exploration of new genetic combinations and the development of new cultivars (Connor \& Towill, 1993), with characteristics different from those already existing. In the literature, the use of this conservation tool for genetic improvement has been described in many crops of economic interest, such as tomato (Sacks \& St. Clair, 1996), papaya (Junior et al., 2015), corn (Davide et al., 2009), bromelia (Parton et al., 2002) and roses (Giovannini et al., 2017).

The efficient preservation of the viability of pollen grains depends on many intrinsic and extrinsic factors, such as the physiological state of the donor plant, the humidity degree and the chemical composition of the pollen grain, and the storage temperature, especially since longevity is reduced rapidly when exposed or maintained at $25^{\circ} \mathrm{C}$ or environmental temperature (Giovanniniet al., 2017; Macovei et al., 2016).

\footnotetext{
Submitted on May 24 th 2019 and accepted on September 26 th 2019

${ }^{1}$ Universidade Federal de São Carlos, Centro de Ciências Agrárias, Programa de Pós-Graduação em Produção Vegetal e Bioprocessos Associados, Araras, São Paulo, Brazil. naiara.vallado@hotmail.com

${ }^{2}$ Universidade Federal de São Carlos, Centro de Ciências Agrárias, Graduanda em Engenharia Agronômica, Araras, São Paulo, Brazil. caa.saziki@outlook.com

${ }^{3}$ Universidade Federal de São Carlos, Departmento de Biotechnologia e Produção Vegetal e Animal, Laboratorio de Fisiologia Vegetal e Cultura de Tecidos, Araras, São Paulo, Brazil jeancardctv@gmail.com

*Corresponding author: jeancardctv@gmail.com
} 
The cold storage of pollen grains can be used in different applications, such as for breeding purposes. The obtaining of interespecific hybrids is of great relevance in floriculture, as it allows to obtain cultivars with mixed characteristics from their parents, using superior cultivars and/or species. The pollen grain storage is of special interest when natural flowering of the parents is difficult. In floriculture, this is especially interesting for the following reasons: the production of new cultivars is based on the use of hybridization techniques, with crosses between elite genotypes, followed by progenies evaluation and selection (Cardoso et al., 2016; Cardoso, 2017) and crosses between species with different flowering periods may result in F1 hybrids with natural flower production in more than one season per year, or even outside the flowering period of their parents (Gomes et al., 2003; Giovannini et al., 2015).

There are different forms of storage for the preservation of pollen viability, reducing the losses in germination along the storage period, such as the cryopreservation in liquid nitrogen $\left(-196{ }^{\circ} \mathrm{C}\right)$ described by Parton et al. (2002), in which the authors stored pollen grains from different species of bromeliads (Aechmea spp and Pitcairnia spp.). Another form of storage is the use of the ultra-freezer $\left(-80^{\circ} \mathrm{C}\right)$, where Wang et al. (2015) obtained a preservation rate of $70 \%$ pollen grains in litchi (Litchi chinensis Sonn) after two years of storage. These methods are mainly aimed at preserving pollen grains for long periods of storage and generally have a higher cost, especially for the purchase of preservation equipment and materials (Fagundes, 2017).

Other simplified methods also use low-temperatures for preservation of pollen grains, but are applied for short periods of storage (days, weeks, months) including freezer storage $\left(-10\right.$ to $\left.-20^{\circ} \mathrm{C}\right)$ and refrigerator $\left(5-10^{\circ} \mathrm{C}\right)$, already reported in Citrus species (Ali \& Perveen, 2014), castor (Vargas et al., 2009), olives (Zambon et al., 2018), roses (Giovannini et al., 2015) and kiwi (Borghezan et al., 2011).

It is important to emphasize that in breeding programs, one objective is the hand cross pollination of species with different bloom season, in which these cheaper techniques of freezer or refrigerator storage meet the demands of the breeders (Zambon et al., 2018), since in this case both parents have at least one flowering throughout the year.

The verification of pollen viability can be determined with the use of staining techniques, in which nuclear dyes such as acetic carmine color the viable pollen grains (Mercier, 1995). Although it is easy application, it may not reflect the real germination capacity, as in some stained pollen grains that are even unable to germinate due to pollen tube growth limitations (Galleta, 1983). Another form of verification is through in vitro germination of pollen grains (Pio et al., 2007) by stimulation of pollen tube growth in culture medium (Almeida et al., 2011).

In vitro germination of pollen grains has as advantages the most convenient and safe method used to test the viability of these ones (Frazon et al., 2015). For Marcellán \& Camadro (1996), this method reveals the true state of the reserves, the condition of the membranes and the use of the pollen grain reserves to the germination. The in vitro germination of pollen grains is influenced by different factors, such as the species, the culture medium, the temperature and the incubation time, the stage of development of the flower when the pollen is collected, and the storage conditions (Stanley \& Linskens, 1974; Sharafi, 2011).

In amaryllis (Hippeastrum sp.), an important ornamental commercial genus with bulbs, one of the difficulties for breeding has been to synchronize the flowering of two varieties for the cross pollination, because the low durability of the flowers and the different times required for the emergence of the flowers of each cultivar.

In amaryllis, previous studies reported pollen viability and pollen grains preservation is practically non-existent, which makes it difficult to understand the success rate in crosses between different hybrids or species, as well as the best technique for storing the pollen grains, aiming at their use in interspecific crosses. Then, the present study aimed to characterize the flowering of five cultivars of amaryllis and evaluate the viability of the use of lowtemperature storage as a form for storage pollen grains.

\section{MATERIAL AND METHODS}

Bulbs of different cultivars of amaryllis previously induced to flowering were supplied by Terra Viva (Holambra, SP). They were planted in plastic pots number 15 (1.4 L capacity) containing peat-based substrate (Pindstrup, Danmark) and washed sand 2:1 (v/v). Cultivation was carried out in a greenhouse covered on the top with agricultural plastic with diffusion technology $(150 \mu \mathrm{m})$ and on the sides with white anti-aphid screen. Plants were irrigated with micro sprinkler, with an applied amount of water of approximately $5 \mathrm{~mm}$ /day. Plants were cultivated until flowering, when anthers were collected and used in the experiment. A single fertilization was performed at planting with the commercial fertilizer 20-2020 in the amount of $1.0 \mathrm{~g} \mathrm{~L}^{-1}$.

\section{Characteristics of flowers and inflorescences of cultivars used for the preservation of pollen grains}

The morphological characterization of the flowers and inflorescences of each cultivar was performed due to their ornamental use and lack of information on the genus. 
These descriptions were carried out for the cultivars 'Bolero', 'Bull', 'Intokazie' 'Olaf' and 'Pink Panther'. The horizontal and vertical diameter of the flowers and height of the first inflorescence were measured and the number of flower buds per inflorescence was counted. Four flowers per cultivar (replicates) were randomly measured from four plants of each cultivar. A morphological description of the inflorescences and flowers of this ornamental group was also carried out.

\section{Storage of pollen grains from different cultivars of amaryllis at different temperatures}

Anthers of the five amaryllis cultivars 'Bolero', 'Bull', 'Intokazie' 'Olaf' and 'Pink Panther' were collected and identified according to the cultivar, and later distributed in Petri dishes containing dried filter paper and kept at room temperature $\left(25 \pm 1^{\circ} \mathrm{C}\right)$ for 24 hours in order to reduce the moisture of the anther, which promotes the opening and release of pollen grains from anthers.

Before initiating storage at different temperatures, the viability of pollen grains of each cultivar was tested using the in vitro germination of the pollen grains in culture medium containing $800 \mathrm{mg} \mathrm{L}^{-1} \mathrm{Ca}\left(\mathrm{NO}_{3}\right)_{2}, 200 \mathrm{mg} \mathrm{L}^{-1} \mathrm{H}_{3} \mathrm{BO}_{3}$, $10 \%$ sucrose and $3 \mathrm{~g} \mathrm{~L}^{-1}$ gelrite. The $\mathrm{pH}$ was adjusted to 6.5 (Pio et al., 2007) before addition of gelrite. The culture medium were disposable in plastic Petri dishes and kept at room temperature until semi-solid consistency was achieved.

Pollen grains were then distributed on the surface of the culture medium. Plates containing culture medium and pollen grains were closed and placed at temperature of 25 $\pm 2{ }^{\circ} \mathrm{C}$ for four hours.

Another part of the pollen grains were packed in 1.5 $\mathrm{mL}$ Eppendorf $\AA$ and stored at the following temperatures: $25^{\circ} \mathrm{C}$ (growth room), $8^{\circ} \mathrm{C}$ (refrigerator) and $-20^{\circ} \mathrm{C}$ (freezer), each temperature being considered as a treatment. The in vitro germination of pollen grains in culture medium was evaluated in different storage periods, at 0 (initial viability), 20, 75, 125, 165, 205 and 245 days.

To evaluate the in vitro germination, corresponding to the viability of pollen grains, a total of 90 pollen grains per replicate were counted using multiple fields of view. Four replicates were considered totaling the count of 360 pollen grains per treatment.

All the visualizations were done with the aid of a Nikon Eclipse 201 optical microscope, at 40X magnification, after four hours from inoculation. Pollen grains were considered germinated only when observed the emergence of the pollen tube (Dafni \& Firmage, 2000). Pollen grains without the presence of pollen tubes were counted as non-viable.

The values obtained from the count of viable pollen grains, in each replicate, were previously transformed in percentage, obtaining the percentage of pollen grains of each cultivar germinated at different storage temperatures. The experimental design was a $5 \times 3$ factorial completely randomized, with five cultivars and three storage temperatures.

Data, expressed as percentage of germination of pollen grains, were previously transformed into arcsine of the square root of $\mathrm{X} / 100$, before performing the analysis of variance and the Tukey's test, at 5\% probability. For the statistical analysis, the AgroEstat software was used (Barbosa \& Maldonado Junior, 2009). In order to show the germination of pollen grains under different temperatures, evaluated in time, the exponential regression with graphical representation was used.

\section{RESULTS AND DISCUSSION}

\section{Characteristics of flowers and inflorescences of cultivars used for preservation of pollen grains}

The cultivars presented morphological differences according to the characteristics of their flowers and inflorescences, with length of inflorescences ranging from 12.5 to $39.9 \mathrm{~cm}$, the lowest value being observed in $\mathrm{cv}$. Bull and the highest value, in cv. Pink Panther (Table 1).

All cultivars presented protected floral buds during initial development by large greenish-colored bracts. At the end of inflorescence development and with increasing size of floral buds, they are emerge out of the bracts, consisting of four to five large flowers allocated to the terminal portion of the inflorescences (Table 1). One or two of these flowers in inflorescence remains with limited development, while the others have faster elongation and culminate in anthesis (Figure 1A). The flower with the most limited development is the last one to present anthesis, being sometimes noticed the senescence of the most developed flowers at the moment in which this flower is still open in the inflorescence.

The flowers are consisted of six tepals, with three sepals and three petals very similar in shape, size and coloration, inferior ovaries, and present six stamens each containing an anther, all of which are viable and produce pollen grains (Figure 1B). The opening of the anthers, initially large and showy, starts in the first hours after anthesis, exposing a large quantity of pollen grains light yellow in color. As the anthers open, they wither, reducing their size considerably and exposing increasingly the pollen grains, which begin to peel off, sometimes 'dirtying' the lower tepals of the flower (Figure 1). This characteristic is sometimes considered bad for commercialization of this type of flower due to the visual impact of pollen grains in tepals. The style is usually more elongated than the stamens, and the triphyde stigma shows later maturation than the pollen grains, becoming open and mucilaginous 3-4 days after the anthesis of the flower buds. 
The flowers, organ of greater visual impact for use as ornamental plant, mainly for their coloration and size, are semi-tubular, with degree of opening of the flowers that allows the partial exposure of the tepals, maintaining an open part (distal portion) and a tubular part with partial exposure (proximal portion) (Figure 1). For all cultivars, the percentage of opening of the flower portion was close to $50 \%$ of the total length of the petals, with no variation between cultivars (Table 1). Another characteristic of the flowers is that they acquire approximately $90-110^{\circ}$ slope in relation to the vertical direction of growth of the inflorescence, keeping the flowers with better visual impact for their commercialization. Flowers of different cultivars showed diverse coloration from white (cv. Intokazie), Pink (cvs. Bolero and Pink Panther) and red (cvs. Bull and Olaf) colours (Figure 2).

The cv. Bull showed the flowers with smallest vertical and horizontal diameters, with equatorial diameter of 9.8 $\mathrm{cm}$ and polar diameter of $8.7 \mathrm{~cm}$. The highest values were found in the flowers of cultivar 'Bolero', $11.7 \mathrm{~cm}$ and 13.0 $\mathrm{cm}$, for equatorial and polar diameters, respectively. On the average, the cultivars presented four to five flower buds per inflorescence (Table 1).

\section{Experiment to preserve the viability of pollen grains stored at different temperatures}

The culture medium used for in vitro germination was viable for pollen grains of the different cultivars of Hippeastrum. This can be demonstrated by the high percentage of pollen grains germinated under these conditions, with a germination percentage of $50-70 \%$ of the pollen grains being quantified, depending on the cultivar used. In order to optimize the germination of oriental lily pollen grains, Jin-Ping \& Jin-Gang (2003) obtained the culture medium with $13 \%$ sucrose, plus $143 \mathrm{mg} \mathrm{L}^{-1}$ boric acid and solidified with $1 \%$ agar. Our present study with Hippeastrum cultivars used the culture medium containing $10 \%$ sucrose, $200 \mathrm{mg} \mathrm{L}^{-1}$ boric acid, with the addition of

Table 1: Inflorescence and flower data measures in different cultivars of amarílis (Hippeastrum sp.)

\begin{tabular}{lccccc}
\hline \multirow{2}{*}{ Cultivar } & $\begin{array}{c}\text { Inflorescence } \\
\text { length }(\mathbf{c m})\end{array}$ & $\begin{array}{c}\text { Number of bud } \\
\text { flowers } / \text { inflorescence }\end{array}$ & \multicolumn{2}{c}{ Flower diameter (cm) } & Color \\
\cline { 4 - 5 } & 33.3 & 4 & Polar & Equatorial & \\
\hline Bolero & 12.5 & 4 & 9.8 & 11.7 & Light Pink \\
Bull & 38.7 & 4 & 11.1 & 8.7 & Dark Red \\
Intokazie & 36.5 & 4 & 12.7 & 11.1 & White \\
Olaf & 39.9 & 5 & 11.4 & 10.1 & Red \\
Pink Panther & 11.2 & - & 1.8 & 1.4 & Pink \\
\hline CV $(\%)$ & & &
\end{tabular}
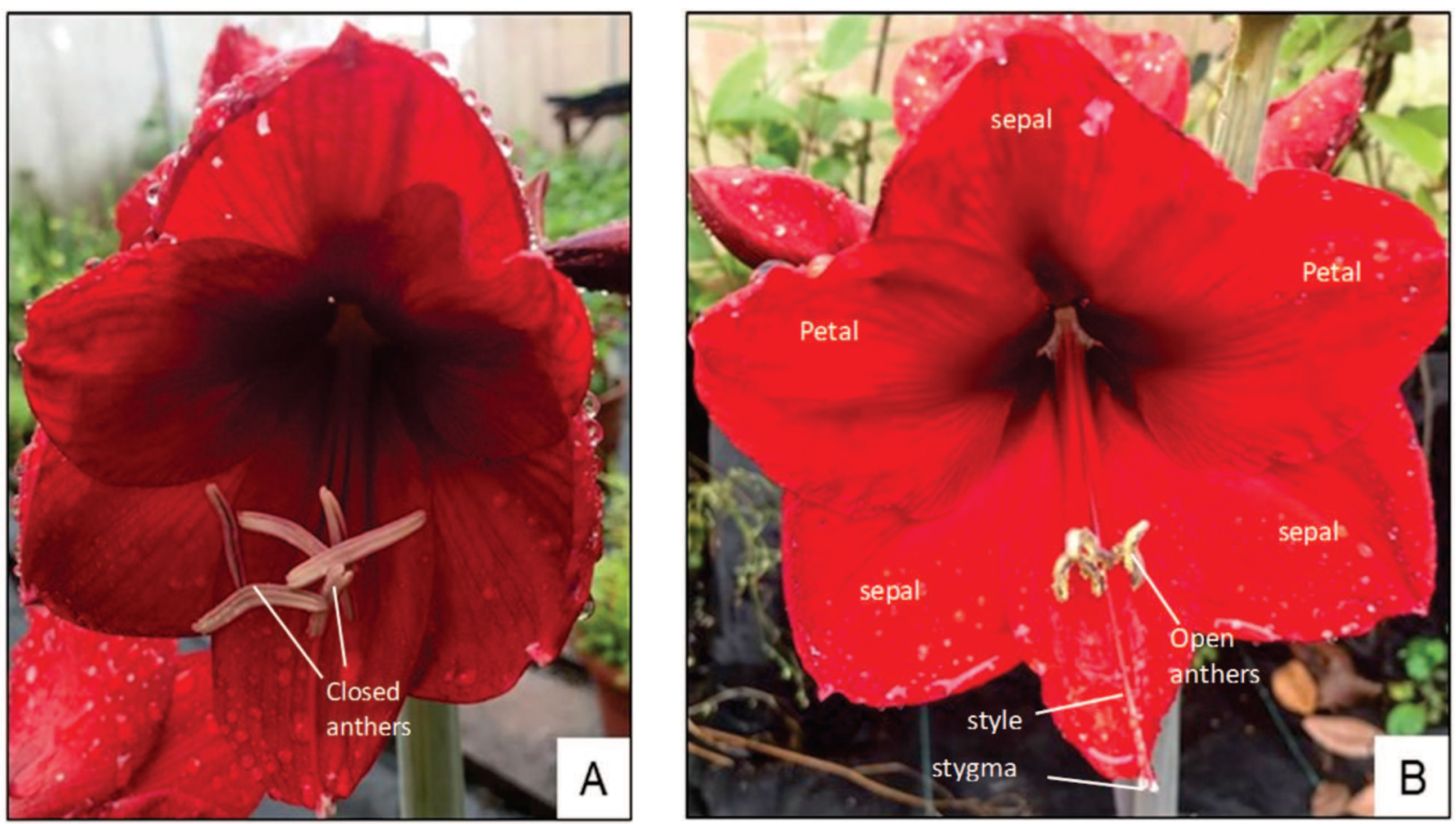

Figure 1: Morphological characteristics of flowers of amaryllis in the first hour (A) and 24 hours after anthesis (B).

Rev. Ceres, Viçosa, v. 66, n.6, p. 451-459, nov/dec, 2019 
$800 \mathrm{mg} \mathrm{L}^{-1}$ calcium nitrate and gelrite as agent for solidification.

The periodic evaluations showed a loss of viability of the pollen grains during the storage time, with a reduction in the percentage of in vitro germination in all evaluated cultivars. The largest and fastest loss of viability occurred at $25^{\circ} \mathrm{C}$.

The cultivar 'Bull' presented complete loss of viability of pollen grains at firstly 75 days of storage, even when stored at low temperatures, while 'Intokazie' cultivar maintained viability of $46-47 \%$ in the same storage period, using low temperatures $\left(8\right.$ or $-20^{\circ} \mathrm{C}$ ) (Table 2; Figure 3 ). The cultivars 'Bolero' and 'Pink Panther' showed more intense reduction in germinability in the first days of storage and after 200 days of storage, while 'Bull' and 'Olaf' presented intense lost of viability (Figure 3). In studies conducted by Albuquerque et al. (2007) on seven cherry cultivars, germination rates were higher than $35 \%$
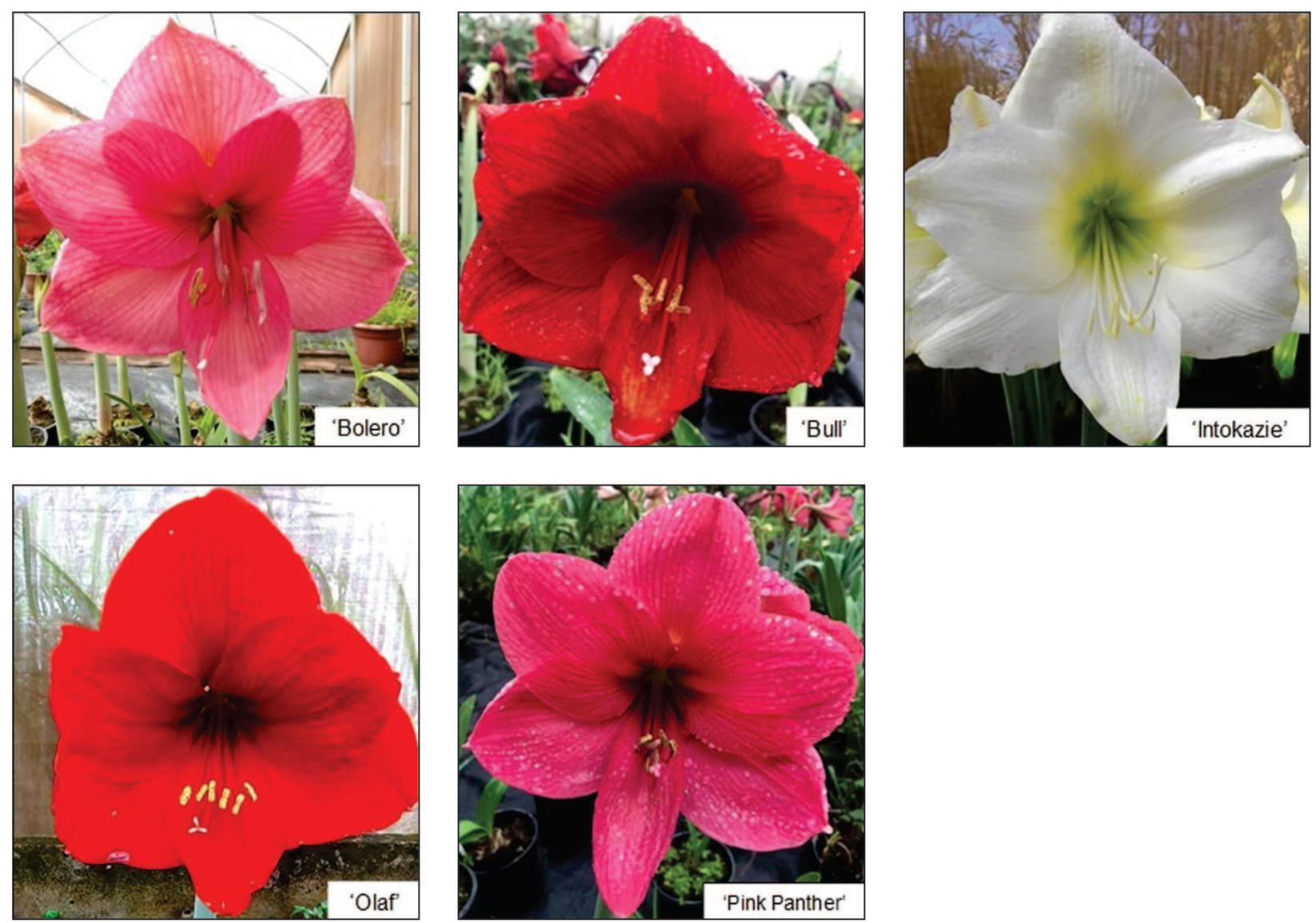

Figure 2: Morphology and flower colours of five cultivars of amaryllis (Hippeastrum sp.)

Table 2: Initial germinability (0-d) and after 75 and 125-d storage at different temperatures of pollen grains of amaryllis (Hippeastrum sp.) cultivars

\begin{tabular}{|c|c|c|c|c|c|c|c|}
\hline \multirow{2}{*}{$\begin{array}{l}\text { Hippeatrum } \\
\text { cultivar }\end{array}$} & \multirow{2}{*}{ 0-d } & \multicolumn{3}{|c|}{ Storage for $75-d$} & \multicolumn{3}{|c|}{ Storage for $125-d$} \\
\hline & & $25^{\circ} \mathrm{C}$ & $8^{\circ} \mathrm{C}$ & $-20{ }^{\circ} \mathrm{C}$ & $25^{\circ} \mathrm{C}$ & $8^{\circ} \mathrm{C}$ & $-20^{\circ} \mathrm{C}$ \\
\hline Bolero & $69.9 \mathrm{a}$ & $0 \mathrm{aB}$ & $32.7 \mathrm{bA}$ & $38.3 \mathrm{bA}$ & $0 \mathrm{aB}$ & $29.9 \mathrm{bA}$ & $33.9 \mathrm{bA}$ \\
\hline Bull & $62.1 \mathrm{~b}$ & $0 \mathrm{aA}$ & $4.6 \mathrm{dA}$ & $0.0 \mathrm{cA}$ & $0 \mathrm{aA}$ & $0.0 \mathrm{~d} \mathrm{~A}$ & $0.0 \mathrm{c} \mathrm{A}$ \\
\hline Intokazie & $55.0 \mathrm{~d}$ & $0 \mathrm{aB}$ & $46.4 \mathrm{aA}$ & $47.0 \mathrm{aA}$ & $0 \mathrm{aB}$ & $49.0 \mathrm{aA}$ & $44.2 \mathrm{aA}$ \\
\hline Olaf & $51.5 \mathrm{e}$ & $0 \mathrm{aC}$ & $28.3 \mathrm{cB}$ & $39.9 \mathrm{bA}$ & $0 \mathrm{aC}$ & $22.2 \mathrm{cB}$ & $36.0 \mathrm{bA}$ \\
\hline Pink Panther & $56.1 \mathrm{c}$ & $0 \mathrm{aB}$ & $45.4 \mathrm{abA}$ & $45.4 \mathrm{Ba}$ & $0 \mathrm{aB}$ & $43.1 \mathrm{aA}$ & $39.4 \mathrm{abA}$ \\
\hline F cultivar & & & & $118.25^{* *}$ & & $133,01 * *$ & \\
\hline F temperature & ne & & & $451.57 * *$ & & $452,49 * *$ & \\
\hline F interaction & ne & & & $31.27 * *$ & & $47.52 * *$ & \\
\hline$\overline{\mathrm{CV}(\%)}$ & 7.79 & & & 18.24 & & 18.23 & \\
\hline
\end{tabular}

Mean followed by the same upper case letter in lines and lower case latters in column, for each period of storage (0, 75 and 125 -d) don't differs statistically each other at $1 \%$ probability by the Tukey test. ne, non-evaluated; CV, coefficient of variation. 
after one year of storage at $-20^{\circ} \mathrm{C}$, however, two cultivars were highly susceptible under the same conditions of storage, evidencing the variation between cultivars and storage temperature.

\section{Storage temperature effect}

The temperature of $25{ }^{\circ} \mathrm{C}$ accelerates the lost of viability and reduced the capacity of storage Hippeastrum pollen grains able to germinate. Similar results were reported by Ye \& Yi-min (2008), in which $20^{\circ} \mathrm{C}$ storage temperature resulted in rapid lost of viability of pollen grains of Hippeastrum, while $4^{\circ}$ and $-18{ }^{\circ} \mathrm{C}$ can be used for until three-month preservation of pollen grains.

Our results also showed that the best storage temperatures were $8{ }^{\circ} \mathrm{C}$ (refrigerator) and $-20^{\circ} \mathrm{C}$ (freezer) for all cultivars of amaryllis (Table 2; Figure 3).

Similar results were reported by Yunwei et al. (2007), who used low temperatures $\left(-20\right.$ and $\left.-80{ }^{\circ} \mathrm{C}\right)$ that resulted in preservation of pollen grain viability above $40 \%$ for Asian lilies cvs. Prato and Polyana, while the temperature of $25{ }^{\circ} \mathrm{C}$ resulted in rapid loss of viability. Rhee et al. (2005) also observed that the temperature of $-20{ }^{\circ} \mathrm{C}$ was one that effectively maintained the pollen viability during storage.

According to Almeida et al., (2011) and Pio et al., (2007), high temperatures lead to dehydration and accelerate pollen grain metabolism, as well as increased respiration rate and conversion of sugars into organic acids, and accumulation of secondary metabolic products cause faster loss of pollen viability (Stanley \& Linskens, 1974). The effect of low temperatures on the preservation of pollen viability is related to the reduction of cellular metabolism, resulting in a longer longevity (Cuchiara et al., 2015, Aloisi etal., 2016).

\section{Effects of the interaction between the cultivar and the storage temperature}

At all storage temperatures, pollen viability reduced with time of storage. However, distinct reductions were observed according to the evaluated cultivar (Table 2). In storage periods of 75 to 125 days, it was possible to detect interaction between cultivar and storage temperature of pollen grains (Figure 3).

The 'Bolero' cultivar was the one with the highest percentage of viable pollen grains $(69.9 \%)$, followed by 'Bull' (62.1\%), 'Pink Panther' (56.1\%), 'Intokazie' (51.5\%). However, it was not possible to observe a correlation between the initial viability and the viability for storage of pollen grains. As an example, we can mention the cultivar 'Bolero' with highest initial viability of pollen grains $(69.9 \%)$ and which has a reduction to $46.8 \%$ and $54.8 \%$ of its initial germinative capacity at first 75 days of storage at temperatures of 8 and $-20^{\circ} \mathrm{C}$. The 'Olaf' cultivar, which showed the lowest initial viability (51.5\%), showed a softer reduction (compared to 'Bolero') to 55 and $77.5 \%$ of its initial germinative capacity at 75 days of storage at temperatures of 8 and $-20^{\circ} \mathrm{C}$. Similarly, the 'Bull' cultivar, which presented the second highest percentage of initial germination $(62.1 \%)$, had its viability drastically reduced at all temperatures, completely losing its viability in the first 75 days of storage (Table 2, Figure 3). The cultivars with the greatest longevity for pollen grains storage were 'Bolero', 'Pink Panther' and 'Intokazie', the first two with pink flowers and the last with white flowers. Similar to cultivar 'Bull', the 'Olaf' cultivar, both with red flowers, were those with less longevity and more recalcitrant to storage (Table 2, Figure 3).

In the present study, it was observed that some cultivars of amaryllis have limited preservation capacity, as is the case of 'Bull'. In a single previous study on preservation of pollen grains of Hippeastrum, Jirakiattikul (1999) evaluated three accessions of Hippeastrum sp. and verified a high in vitro pollen viability in two accessions for 104 weeks when stored at temperatures of -18 and -80 ${ }^{\circ} \mathrm{C}$ with viability percentage above $50 \%$, but in one of the accessions the drastic decrease in viability occurred after 64 weeks at $2{ }^{\circ} \mathrm{C}$, and after 104 weeks, it had lost total germination capacity.

In tomato (Lycopersicum esculentum), the long-therm storage of pollen grains resulted in loss of these pollen grains to synthesize proteins, polyamine biosynthetic enzymes and polyamines contents, resulting in low germination rates. The addition of $1 \mathrm{mM}$ of polyamines putreschine, spermine or spermidine restored the germination capacity and fertilization ability (Song \& Tachibana, 2007), showing a possible correlation with polyamine biosynthesis and storage capacity of different genotypes.

Low temperature storage of pollen grains is an important strategy and help breeders to develop new cultivars through hybridization, especially in those species in which the durability of the flowers is reduced and the synchronization of flowering is difficult (Giovannini et al., 2017; Zambon et al., 2018).

This is the case of the cultivars of amaryllis evaluated herein, in which the durability of the flowers is relatively short, around 5-10 days from anthesis to the beginning of flower senescence, as well as the beginning of the development of the inflorescence is affected by different factors, such as the presence of diseases in the bulb, the size of the bulb and the conditions and time of storage of pollen grains. These factors make exact synchronization of flowering difficult, which is required to perform the cross-pollination aiming hybridization.

In this way, the storage of pollen grains at low temperatures is a viable and inexpensive solution for 

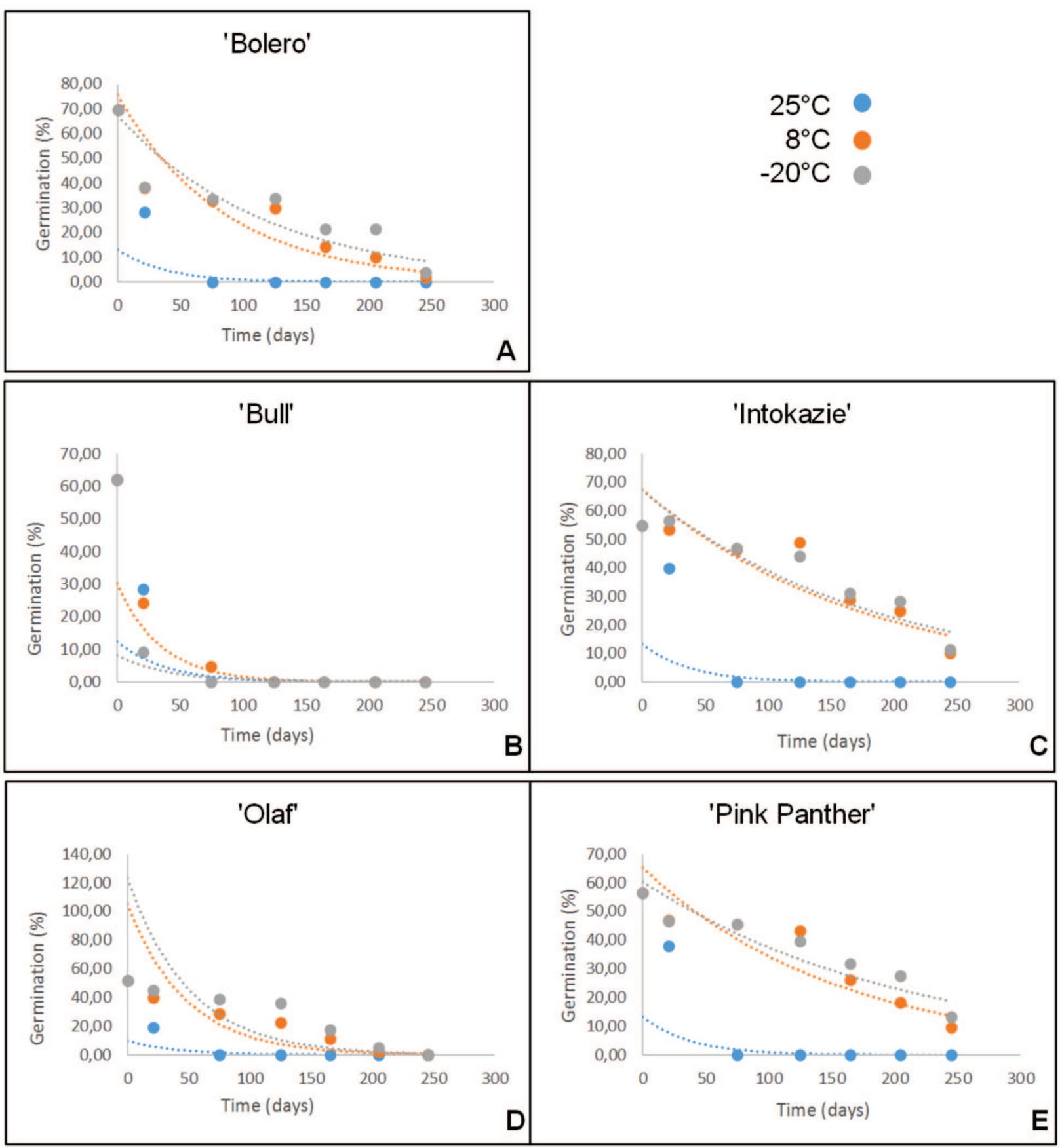

A $\begin{aligned} 25^{\circ} \mathrm{C}: \mathrm{y}=13,028 \mathrm{e}^{-0,026 x} & \mathrm{R}^{2}=0,6542 \\ 8^{\circ} \mathrm{C}: \mathrm{y}=75,538 \mathrm{e}^{-0,012 x} & \mathrm{R}^{2}=0,8346 \\ -20^{\circ} \mathrm{C}: \mathrm{y}=67,285 \mathrm{e}^{-0,008 x} & \mathrm{R}^{2}=0,7303\end{aligned}$

B $25^{\circ} \mathrm{C}: \mathrm{y}=12,418 \mathrm{e}^{-0,026 x} \quad \mathrm{R}^{2}=0,6542$ $8^{\circ} \mathrm{C}: \mathrm{y}=30,267 \mathrm{e}^{-0,029 x} \quad \mathrm{R}^{2}=0,843$ $-20^{\circ} \mathrm{C}: \mathrm{y}=8,1668 \mathrm{e}^{-0,024 x} \quad \mathrm{R}^{2}=0,6446$

C

$25^{\circ} \mathrm{C}: \mathrm{y}=13,391 \mathrm{e}^{-0,026 \mathrm{x}}$

$8^{\circ} \mathrm{C}: \mathrm{y}=67,597 \mathrm{e}^{-0,006 \mathrm{x}}$

$-20^{\circ} \mathrm{C}: \mathrm{y}=67,197 \mathrm{e}^{-0,005 x}$
$R^{2}=0,6525$

$R^{2}=0,7808$

$R^{2}=0,7943$
D

$$
\begin{array}{rr}
25^{\circ} \mathrm{C}: \mathrm{y}=9,8222 \mathrm{e}^{-0,025 x} & \mathrm{R}^{2}=0,6538 \\
8^{\circ} \mathrm{C}: \mathrm{y}=105,28 \mathrm{e}^{-0,021 x} & \mathrm{R}^{2}=0,7673 \\
-20^{\circ} \mathrm{C}: \mathrm{y}=123,21 \mathrm{e}^{-0,02 x} & \mathrm{R}^{2}=0,6599
\end{array}
$$

E

$$
\begin{aligned}
25^{\circ} \mathrm{C}: \mathrm{y}=13,265 \mathrm{e}^{-0,026 x} & \mathrm{R}^{2}=0,653 \\
8^{\circ} \mathrm{C}: \mathrm{y}=65,353 \mathrm{e}^{-0,006 x} & \mathrm{R}^{2}=0,8517 \\
-20^{\circ} \mathrm{C}: \mathrm{y}=60,501 \mathrm{e}^{-0,005 x} & \mathrm{R}^{2}=0,8212
\end{aligned}
$$

Figure 3: Regression analysis for storage period and in vitro germinability of pollen grains of different cultivars of amaryllis submitted to different temperatures for preservation of viability. 
application in the breeding of this ornamental group, aiming the use of controlled crossings in which the synchronization of flowering is quite difficult. The maintenance of good germination capacity for 'Intokazie' and 'Pink Panther' (43-49\% germination) and 'Olaf' and 'Bolero' cultivars (34-39\%) for a period of 125 days are sufficient to allow most crosses between species or even between other cultivars, considering the use of preinduced flowering bulbs, the main method commercially used for induction of flowers for commercialization and controlled cross-pollination.

Among the cultivars tested, the 'Bull' requires additional studies on the causes of the accelerated and intense loss of pollen viability during storage, as well as studies to understand the greater loss of viability in red flower cultivars, as observed in our study.

\section{CONCLUSION}

The different cultivars showed differences in flowering, especially in relation to color and size of flowers and inflorescences that could be usefull for breeding purposes.

The preservation of pollen grains of amaryllis at low temperatures extended the life of pollen grains for most of cultivars.

Storage at low temperatures can be used as a tool in breeding programs of this important ornamental species.

\section{ACKNOWLEDGEMENTS}

JCC and NVA thanks to Terra Viva (Santo Antônio de Posse, Brazil) for financial support and sourced the plants for this study, by means of Proex/UFSCar Process number 23112.004431/2017-30. Special thanks to Dr. Everton Gomes da Costa (Terra Viva) for it intellectual and practical contributions to this paper. This work was supported by the Coordenação de Aperfeiçoamento de Pessoal de Nível Superior [001]. JCC thanks to CNPQ for the processes number 304174/2015-7 and 311083/2018-8.

\section{CONFLICT OF INTEREST}

The authors declare that there is no conflict of interestin carrying thisresearch and publishing this manuscript.

\section{REFERENCES}

Ahmed S, Rattanpal HS, Ahmad E, \& Singh G (2017) Influence of storage duration and storage temperature on in-vitro pollen germination of citrus species. Internacional Journal of Current Microbiology and Applied Sciences, 5:892-902.

Ali S \& Perveen A (2014) In vitro pollen germination of five citrus species. Pakistan Journal of Botany, 46:951-956.
Aloisi I, Cai G, Serafini-Fracassini D \& Del Duca S (2016) Polyamines in pollen: from microsporogenesis to fertilization. Frontiers in Plant Science, 7:01-07.

Albuquerque N, García-Montiel F \& Burgos L (2007) Influence of storage temperature on the viability of sweet cherry pollen. Spanish Journal of Agricultural Research, 5:86-90.

Almeida C, Amaral AL, Neto JFB \& Sereno MJCM (2011) Conservação e germinação in vitro de pólen de milho (Zea mays subsp. mays). Revista Brasileira de Botânica, 34:493-497.

Barbosa JC \& Maldonado Júnior W (2009) Software AgroEstat: Sistema de análises estatísticas de ensaios agronômicos. Versão 1.1.0.712. Jaboticabal, Universidade Estadual Paulista Júlio Mesquita Filho. CD-ROM

Borghezan M, Clauman AD, Steinmacher DA, Guerra MP \& Orth AI (2011) In vitro viability and preservation of pollen grain of kiwi (Actinidia chinensis var. deliciosa (A. Chev.) A. Chev). Crop Breeding and Applied Biotechnology, 11:338-344.

Cardoso JC (2017) Ionocidium 'Cerrado 101': intergeneric orchid hybrid with high quality of blooming. Ornamental Horticulture, 3:351-356.

Cardoso JC, Martinelli AP \& Teixeira da Silva JA (2016) A novel approach for the selection of Cattleya hybrids for precocious and season-independent flowering. Euphytica, 210:143-150.

Mercier S (1995) The role of pollen bank in the tree genetic improvement program in Quebéc (Canada). Grana, 34:367-370.

Connor KF \& Towill LE (1993) Pollen-handling protocol and hydration/dehydration characteristics of pollen for application to long-termstorage. Euphytica, 68:77-84.

Cuchiara CC, Silva DAS \& Bobrowski VL (2015) Conservação de grãos de pólen de mamoneira a baixas temperaturas. Revista Ceres, 59:81-87.

Dafni A \& Firmage D (2000) Pollen viability and longevity: practical, ecological and evolutionar implications. Plant Systematics and Evolution, 222:113-132.

Davide LM, Pereira RC, Abreu GB, Souza JC \& Pinho EVRV (2009) Viabilidade de pólen de milho em diferentes períodos de armazenamento em baixa temperatura. Revista Brasileira de Milho e Sorgo, 8:199-206.

Fagundes MCP (2017) Conservation viability of dragon fruit (Hylocereys polyrhizus Weber) pollen grains. Tese de Doutorado. Universidade Federal de Lavras, Lavras. 48p.

Franzon RC, Raseira MCB \& Júnior AW (2015) Germination of Campomanesia anthocarpa Berg pollen in vitro. Revista Ceres, 53:129-134.

Galletta GJ (1983) Pollen and Seed Management. In: Moore JN \& Janick J (Eds.) Methods in fruit breeding. West Lafayette, Purdue University Press. p.23-35.

Giovannini A, Macovei A, Caser M, Mansuino A, Ghione GG, Savona M, Carbonera D, Scariot V \& Balestrazzi A (2017) Pollen grain preservation and fertility in valuable commercial rose cultivars. Plants, 6:01-08.

Giovannini A, Macovei A, Donà M, Valassi A, Caser M, Mansuino A, Ghione GG, Carbonera D, Scariot V \& Balestrazzi A (2015) Polen grain preservation at low temperature in valuable commercial rose cultivar. Acta Horticulturae, 1064:63-66.

Gomes PR, Raseira MCB, Baudet LL \& Peske ST (2003) Armazenamento do grão de pólen de cebola (Allium cepa L.). Revista Brasileira de sementes, 25:14-17.

Jin-Ping CDF \& Jin-Gang WANG (2003) Study on optimization of the culture medium for oriental hybrids pollen germination. Bulletin of Botanical Research, 2:S.682.29. 
Jirakiattikul Y (1999) Study of intergeneric hybridization in Hippeastrum. PhD Thesis. Kasetsart University, Hobart. 203p.

Junior PCD, Viana AP \& Pereira MG (2015) Comportamento floral de híbridos de mamoeiro (Carica papaya L.) avaliados no verão e na primavera. Revista Ceres, 55:310-316.

Ye L \& Yi-min (2008) Research on pollen germination and pollen preservation characteristic of Hippeatrum. Journal of Shanghai Jiatong University, 1:S.682.25

Yunwei D, Tingting J \& Shuanglin D (2007) Stress responses to rapid temperature changes of the juvenile sea cucumber (Apostichopus japonicas Selenka). Journal of Ocean University of China, 6:275-280.

Macovei A, Caser M, Donà M, Valassi A, Giovannini A, Carbonera D, Scariot V \& Balestrazzi A (2016) Prolonged cold storage affects pollen viability and germination along with hydrogen peroxide andnitric oxide content in Rosa hybrida. Notulae Botanicae Horti Agrobotanici Cluj-Napoca, 44:06-10.

Marcellán ON \& Camadro EL (1996) The viability of asparagus pollen after storage at low temperatures. Scientia Horticulturae, 67:101-104.

Parton E, Vervaeke I, Delen R, Vandenbussche R, Deroose R \& Proft MD (2002) Viability and storage of bromeliad pollen. Euphytica, 125:155-161.

Pio LAS, Ramos JD, Pasqual M, Junqueira KP, Santos FC \& Rufini JCM (2007) Viabilidade do pólen de laranjas doces em diferentes condições de armazenamento. Ciência e Agrotecnologia, 31:147-153.

Rhee HK, Lim JH \& Van Tuyl JM (2005) Improvement of breeding efficiency for interspecific hybridizationo flilies in Korea. Acta Horticulturae, 673:107-112.
Sacks EJ \& St. Clair DA (1996) Cryogenic storage of tomato pollen: effect on fecundity. Horticultural Science, 31:447-448.

Sharafi Y (2011) An investigation on the pollen germination and tube growth in some Prunus persica genotypes and cultivars. African Journal of Microbiology Research, 5:2003-2007.

Song J \& Tachibana S (2007) Loss of viability of tomato pollen during long-term dry storage is associated with reduced capacity for translating polyamine biosynthetic enzyme genes afterrehydration. Journal of Experimental Botany, 58:42354244.

Stanley RG \& Liskens HF (1974) Pollen: Biology, Biochemistry, Management. New York, Springer-Verlag. 310p.

Universidade Estadual Paulista (2009) AgroEstat: Sistema de análises estatísticas de ensaios agronômicos. Faculdade de Ciências Agrárias e Veterinárias. Câmpus de Jaboticabal. Software.

Vargas DP, Souza SAM, Silva DAS \& Bobrowski VL (2009) Análise dos grãos de pólen de diferentes cultivares de mamona (Ricinus communis L., Euphorbiaceae): conservação e viabilidade. Arquivos do Instituto Biológico, 76:115-120.

Vaknin Y \& Eisikowitch D (2000) Effects of short term storage on germinability of pistachio pollen. Plant Breeding, 119:347350 .

Wang L, Wu L, Chen J, Fu D, Zhang C, Cai C \& Ou L (2015) A simple pollen collection, dehydration, and long-term storage method for litchi (Litchi chinensis Sonn.). Scientia Horticulturae, 188:78-83.

Zambon CR, Silva LFO, Pio R, Bianchini FG \& Oliveira AF (2018) Storage of pollen and properties of olive stigma for breeding purposes. Revista Ciência Agronômica, 49:291-297. 